Check for updates

Cite this: RSC Adv., 2019, 9, 25703

\title{
Halide exchange studies of novel Pd(II) NNN-pincer complexes $\uparrow$
}

\author{
Seher Kuyuldar, (D) ab Clemens Burda (D) *b and William B. Connick ta $^{a}$
}

Palladium(॥) complexes with an NNN type pincer ligand ( pip $_{2} N N N=2,6$-bis(piperdyl-methyl)pyridine) are synthesized and characterized. Electronic and ${ }^{1} \mathrm{H}$ NMR spectra point to decreasing filled/filled repulsions between the $\mathrm{d} \pi(\mathrm{Pd})$ orbitals and the halide lone pair orbitals along the $\mathrm{Cl}<\mathrm{Br}<\mathrm{I}$ series. For all complexes, the most downfield $\alpha$-piperidyl resonance of the $\operatorname{pip}_{2} N N N$ ligand is sensitive to changes in the coordinated halide while the meta-pyridyl and benzylic resonances are sensitive to changes in the counter anion. This sensitivity is utilized to study halide association and exchange at the fourth coordination site. Conductivity and ${ }^{1} \mathrm{H}$ NMR spectroscopy confirm the interaction between the exogenous anion $\left(\mathrm{Cl}^{-}, \mathrm{Br}^{-}, \mathrm{BF}_{4}^{-}\right)$and $\mathrm{Pd}\left(\mathrm{pip}_{2} \mathrm{NNN}\right) \mathrm{X}^{+}(\mathrm{X}=\mathrm{Cl}, \mathrm{Br})$.

Received 15th July 2019

Accepted 5th August 2019

DOI: 10.1039/c9ra05423e

rsc.li/rsc-advances various anions $\left(\mathrm{Cl}^{-}, \mathrm{Br}^{-}, \mathrm{I}^{-}, \mathrm{BF}_{4}{ }^{-}\right)$and study the effect of the coordinating halide and the counter-anion by ${ }^{1} \mathrm{H}$ NMR spectroscopy. We will able to investigate halide exchange at the fourth coordination site because pip $_{2} \mathrm{NNN}$ is sensitive to the kind of halide and mode of interaction. Understanding the role of coordinated halide versus the anion has the potential to shed light into competing metal site interactions in catalytic systems with square planar geometries, especially platinum and palladium catalysts.

\section{Results and discussion}

\section{Synthesis of $\operatorname{Pd}\left(\operatorname{pip}_{2} \mathrm{NNN}\right) \mathrm{X}^{+}$salts}

Salts of $\mathrm{Pd}\left(\operatorname{pip}_{2} \mathrm{NNN}\right) \mathrm{X}^{+}(\mathrm{X}=\mathrm{Cl}, \mathrm{Br}, \mathrm{I})$, hereafter referred to as $[\mathrm{X}]^{+}$, are readily prepared by stirring either $\operatorname{PdX}_{2}$ or $\operatorname{Pd}(C O D) X_{2}$ (COD $=1,5$-cyclooctadiene) in acetonitrile solution of $\operatorname{pip}_{2} \mathrm{NNN}$ (Scheme 1). Depending on the reaction conditions, salts with
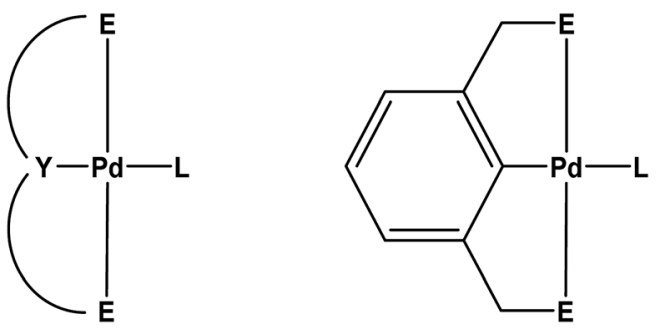

$$
\begin{aligned}
& \mathrm{Y}=\mathrm{C}, \mathrm{N}, \mathrm{P}, \mathrm{Si} \\
& \mathrm{E}=\mathrm{NR}_{2}, \mathrm{PR}_{2}, \mathrm{OR}, \mathrm{SR}, \mathrm{SeR} \\
& \mathrm{L}=\text { monodentate ligands }
\end{aligned}
$$

Chart 1 General depiction of palladium pincer complexes. 


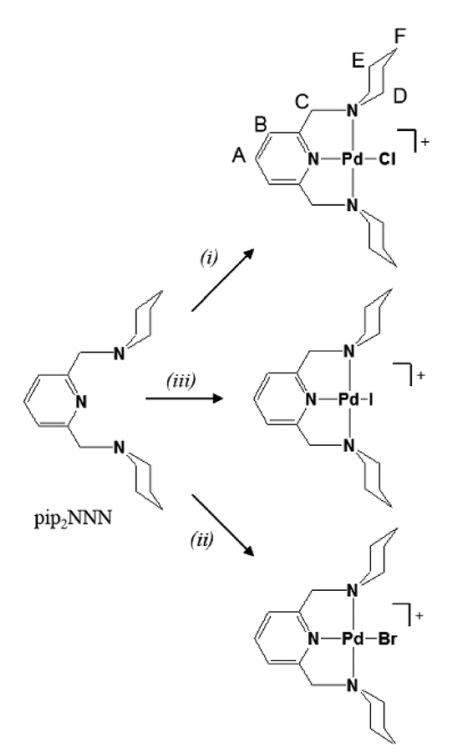

Scheme 1 Synthesis of $\mathrm{Pd}\left(\mathrm{pip}_{2} N N N\right) X^{+}(X=C l, B r$, I) salts. (i) $\mathrm{Pd}(C O D)$ $\mathrm{Cl}_{2}$ or $\mathrm{PdCl}_{2}$, acetonitrile, $40^{\circ} \mathrm{C}$. (ii) $\mathrm{Pd}(\mathrm{COD}) \mathrm{Br}_{2}$ or $\mathrm{PdBr}_{2}$, acetonitrile, $\mathrm{RT}$. (iii) $\mathrm{Pdl}_{2}$, acetonitrile, $50^{\circ} \mathrm{C}$. The unequal protons are labelled $(\mathrm{A}-\mathrm{F})$ on $\mathrm{Pd}\left(\mathrm{pip}_{2} \mathrm{NNN}\right) \mathrm{Cl}^{+}$.

$\mathrm{X}^{-}, \mathrm{PdX}_{4}{ }^{2-}$ and/or $\mathrm{Pd}_{2} \mathrm{X}_{6}{ }^{2-}$ counter anions are obtained. More information about the synthesis, isolation, elemental analyses, UV-visible absorption spectroscopy, and positive and negative mass spectroscopy and of the $\mathrm{PdX}_{4}{ }^{2-}$ and/or $\mathrm{Pd}_{2} \mathrm{X}_{6}{ }^{2-}$ salts are provided in the ESI. $\dagger$ Briefly, the $\mathrm{X}^{-}, \mathrm{PdX}_{4}{ }^{2-}$ and/or $\mathrm{Pd}_{2} \mathrm{X}_{6}{ }^{2-}$ salts have nearly identical ${ }^{1} \mathrm{H}$ NMR spectra in acetonitrile, but are readily distinguished by their colors, solubilities, negative anion mass spectra, electronic absorption spectra, and elemental analyses. The $\mathrm{Cl}^{-}, \mathrm{Br}^{-}$and $\mathrm{I}^{-}$salts are obtained as pure compounds, whereas samples containing $\mathrm{PdX}_{4}{ }^{2-}$ or $\mathrm{Pd}_{2} \mathrm{X}_{6}{ }^{2-}$ are usually mixed with one or both of the other two anions. The halide salts form yellow to orange solutions, whereas salts containing $\operatorname{Pd}_{n} \mathrm{X}_{2 n+2}{ }^{2-}$ anions $(n=1,2)$ are only weakly soluble in acetonitrile and give yellow solutions in the case of $\mathrm{X}=\mathrm{Cl}, \mathrm{Br}$ and red-brown solutions in the case of $\mathrm{X}=\mathrm{I}$. ${ }^{1} \mathrm{H}$ NMR and mass spectra, as well as elemental analyses, confirm that the yellow/orange major products isolated from the filtrates are the halide salts of $[\mathrm{X}]^{+}$. In contrast, for each reaction, the elemental analysis of the less soluble minor product is consistent with having $\mathrm{PdX}_{4}{ }^{2-}$ and/or $\mathrm{Pd}_{2} \mathrm{X}_{6}{ }^{2-}$ as counter anions.

\section{Electronic spectroscopy}

To better understand the electronic structures of the complexes with the $\operatorname{pip}_{2} \mathrm{NNN}$ ligand, absorption spectra of acetonitrile solutions of the halide salts of $[\mathrm{X}]^{+}$were recorded. The data are collected in Table 1 and the spectra are shown in Fig. 1.

For $[\mathrm{X}] \mathrm{X}$, the UV region is dominated by intense absorptions between 200 and $280 \mathrm{~nm}$ (Fig. 1). Since the free ligand absorbs moderately in this region $\left(265 \mathrm{~nm}, 3800 \mathrm{~cm}^{-1} \mathrm{M}^{-1}\right)$, these bands most likely have some contribution from ligand-based transitions. There is a moderately intense shoulder at $297 \mathrm{~nm}$
(5600 $\left.\mathrm{cm}^{-1} \mathrm{M}^{-1}\right)$ in the [I]I spectrum. $\mathrm{Pd}\left(\mathrm{pip}_{2} \mathrm{NCN}\right) \mathrm{X}(\mathrm{X}=\mathrm{Cl}, \mathrm{Br}$, I) complexes exhibit slightly weaker absorption bands at shorter wavelengths (265-285 $\mathrm{nm}, 2000-4000 \mathrm{~cm}^{-1} \mathrm{M}^{-1}$ ) that have been assigned as having significant MLCT character involving the $\operatorname{pip}_{2} \mathrm{NCN}^{-}$ligand. ${ }^{38}$ The MLCT transitions of the $\operatorname{pip}_{2} \mathrm{NNN}$ complexes are expected to occur at longer wavelengths because the greater $\pi$-acceptor capability of pip $_{2} \mathrm{NNN}$. Therefore, this band is tentatively assigned as having significant MLCT character involving $\operatorname{pip}_{2} \mathrm{NNN}$. The transition is anticipated to be shifted to shorter wavelengths in the spectra of the $[\mathrm{Cl}] \mathrm{Cl}$ and $[\mathrm{Br}] \mathrm{Br}$ complexes, and hence obscured by other transitions. In support of this assignment, it is noteworthy that the lowest spin-allowed MLCT transition of $\operatorname{Pd}(4-\mathrm{mbpy}) \mathrm{I}_{2}$ (4-mbpy $=4,4^{\prime}$ dimethyl-2,2'-bipyridine) occurs near $306 \mathrm{~nm}\left(18400 \mathrm{~cm}^{-1}\right.$ $\mathrm{M}^{-1}$, in DMF). ${ }^{39}$

A broad charge transfer feature appears at longer wavelengths in the spectrum of each halide complex, $[\mathrm{Cl}] \mathrm{Cl}(362 \mathrm{~nm}$, $\left.1000 \mathrm{~cm}^{-1} \mathrm{M}^{-1}, \mathrm{FWHM}=2100 \mathrm{~cm}^{-1}\right) ;[\mathrm{Br}] \mathrm{Br}\left(376 \mathrm{~nm}, 850 \mathrm{~cm}^{-1}\right.$ $\left.\mathrm{M}^{-1}, \mathrm{FWHM}=2250 \mathrm{~cm}^{-1}\right)$ and [I]I (421sh $\mathrm{nm}, 800 \mathrm{~cm}^{-1} \mathrm{M}^{-1}$, FWHM $=2300 \mathrm{~cm}^{-1}$ ). A comparison to related complexes suggests that this band is unlikely to have MLCT character. For example, the lowest spin-allowed metal-to-ligand(pyridyl) charge-transfer band of Pt(2,6-bis(aminomethyl)pyridine) $(\mathrm{OH})^{+}$in aqueous solution is shifted to the blue of $320 \mathrm{~nm},{ }^{\mathbf{4 0}}$ and the corresponding transition for the palladium(II) analog is expected to occur at even shorter wavelengths.

Similarly, the lowest spin-allowed metal-to-ligand(bpy) charge-transfer transition of $\mathrm{Pd}(\mathrm{bpy}) \mathrm{Cl}_{2}$ (bpy $=2,2^{\prime}$-bipyridine) occurs near $320 \mathrm{~nm}$ in aqueous solution; ${ }^{41}$ the MLCT transition of $[\mathrm{X}]^{+}$is expected to occur at shorter wavelengths because of the stabilization of the unoccupied $\pi^{*}$ (bpy) level relative to the $\pi^{*}\left(\right.$ pip $\left._{2} \mathrm{NNN}\right)$ level. On the other hand, there are several examples of palladium(II) complexes that are believed to exhibit LMCT transitions in the $>300 \mathrm{~nm}$ region, ${ }^{\mathbf{4 2 - 4 4}}$ including trans$\operatorname{Pd}\left(\mathrm{PPh}_{3}\right)_{2} \mathrm{Cl}_{2}\left(\mathrm{CH}_{2} \mathrm{Cl}_{2}: 345 \mathrm{~nm}, 20135 \mathrm{~cm}^{-1} \mathrm{M}^{-1}, \mathrm{FWHM} \sim\right.$ $\left.3000 \mathrm{~cm}^{-1}\right),{ }^{45,46}$ cis-Pd(dbcpe) $\mathrm{Br}_{2}\left(\mathrm{CH}_{3} \mathrm{CN}: 354 \mathrm{~nm}, 14600 \mathrm{~cm}^{-1}\right.$ $\left.\mathrm{M}^{-1}\right)$, cis-Pd(dbcpe) $\mathrm{I}_{2}\left(\mathrm{CH}_{3} \mathrm{CN}: 396 \mathrm{~nm}, 6300 \mathrm{~cm}^{-1} \mathrm{M}^{-1}\right)^{47}$ and Pd(TPA)Cl ${ }^{+}$(DMSO: $338 \mathrm{~nm}, 485 \mathrm{~cm}^{-1} \mathrm{M}^{-1} ; 380 \mathrm{~nm}, 416 \mathrm{~cm}^{-1}$ $\left.\mathrm{M}^{-1}\right)^{48}$ (dbcpe = 1,2-bis[di(benzo-15-crown-5)phosphino]ethane ligand; TPA $=$ tris(2-pyridylmethyl)amine). By analogy, the long wavelength band in the spectra of $[\mathrm{X}]^{+}$is tentatively assigned to a transition having significant $\mathrm{p} \pi\left(\mathrm{X}^{-}\right) \rightarrow \mathrm{d}_{x^{2}-y^{2}}(\mathrm{Pd})$ chargetransfer character. There is considerable variability in the intensities of reported long wavelength LMCT transitions of palladium(II) complexes. The comparatively low intensities of the bands in the spectra of $[\mathrm{X}]^{+}$may be a consequence of spinforbidden character. An alternative explanation is that these bands arise from a ligand field transition. The red shift of this band along the halide series $\mathrm{Cl}<\mathrm{Br}<\mathrm{I}$ is in accord with either assignment.

The $\sim 1000 \mathrm{~cm}^{-1}$ red shift from $\mathrm{Cl}$ to $\mathrm{Br}$ and the $\sim 2800 \mathrm{~cm}^{-1}$ red shift from $\mathrm{Br}$ to I fall within the range of shifts in LMCT bands reported for square planar $\mathrm{d}^{8}$ complexes such as $\mathrm{Pd}(\mathrm{dbcpe}) \mathrm{X}_{2}\left(800,3000 \mathrm{~cm}^{-1}\right),{ }^{47}$ trans $-\left[\mathrm{Pd}_{2}\left(\mathrm{P}(\mathrm{Et})_{2} \mathrm{CH}_{2} \mathrm{P}(\mathrm{Et})_{2}\right)_{2} \mathrm{X}_{4}\right]$ $\left(\mathrm{Cl}-\mathrm{Br}, 1690 \mathrm{~cm}^{-1}\right)^{49}$ and $\mathrm{Ni}\left(\mathrm{Cynp}_{3}\right) \mathrm{X}^{+}\left(700,3000 \mathrm{~cm}^{-1}, \mathrm{Cynp}_{3}=\right.$ tris(2-dicyclohexylphosphinoethyl)amine). ${ }^{\mathbf{5 0}}$ 
Table 1 UV-vis absorption data for $\left[\mathrm{Pd}\left(\operatorname{pip}_{2} N N N\right) \mathrm{Cl}\right] \mathrm{Cl}$, $\left[\mathrm{Pd}\left(\operatorname{pip}_{2} N N N\right) B r\right] B r$, and $\left[\mathrm{Pd}\left(\operatorname{pip}_{2} N N N\right) I\right]$

\begin{tabular}{ll}
\hline Compound & $\lambda_{\max } / \mathrm{nm}\left(\varepsilon / \mathrm{cm}^{-1} \mathrm{M}^{-1}\right)$ \\
\hline$\left[\mathrm{Pd}\left(\mathrm{pip}_{2} \mathrm{NNN}\right) \mathrm{Cl}\right] \mathrm{Cl}$ & $209(34200), 252(13150), 277 \mathrm{sh}(4300), 362(1000)$ \\
{$\left[\mathrm{Pd}\left(\mathrm{pip}_{2} \mathrm{NNN}\right) \mathrm{Br}\right] \mathrm{Br}$} & $218(29300), 266 \mathrm{sh}(10200), 277 \mathrm{sh}(6700), 376(850)$ \\
{$\left[\mathrm{Pd}\left(\mathrm{pip}_{2} \mathrm{NNN}\right) \mathrm{I}\right] \mathrm{I}$} & $205(32700), 249(29600), 277 \mathrm{sh}(11400), 297 \mathrm{sh}(5600), 421(800)$
\end{tabular}

\section{${ }^{1}$ H NMR spectroscopy}

A general labeling scheme for inequivalent protons is shown in Scheme 1 for $\left[\mathrm{Pd}\left(\mathrm{pip}_{2} \mathrm{NNN}\right) \mathrm{Cl}\right]^{+}$. The ${ }^{1} \mathrm{H}$ NMR spectra of $[\mathrm{X}]^{+}(\mathrm{X}=$ $\mathrm{Cl}, \mathrm{Br}, \mathrm{I})$ in acetonitrile exhibit patterns consistent with $\mathrm{C}_{2}$ symmetry and are qualitatively similar to those of their pip $_{2}$ $\mathrm{NCN}^{-}$palladium and platinum analogs. ${ }^{33,37} \mathrm{~A}$ triplet and a doublet due to the para and meta protons of the pyridyl ring (A, B) occur between 7.4 and 8.15 ppm (Fig. 2). The benzylic protons (C) give rise to a singlet near $4.6 \mathrm{ppm}$, suggesting a relatively low barrier to move the benzylic groups in and out of the coordination plane. For $[\mathrm{Cl}]^{+}$, the $\alpha$-piperidyl proton resonance at $3.29 \mathrm{ppm}\left(\mathrm{D}^{\prime \prime}\right)$ has the appearance of a doublet and is assigned accordingly to the equatorial proton; the resonance at $4.02 \mathrm{ppm}$ $\left(\mathrm{D}^{\prime}\right)$ has the appearance of a triplet and is assigned to the axial proton. These assignments reflect the expectation of strong coupling between the axial $\alpha$ - and $\beta$-protons. ${ }^{51}$ The remaining aliphatic proton resonances (E, F) appear as complex multiplets further up field (1.4-1.9 ppm). As expected, the spectra of the complexes with $\mathrm{X}^{-}$and $\mathrm{Pd}_{n} \mathrm{X}_{2 n+2}{ }^{2-}$ counter-anions are essentially identical in $\mathrm{CD}_{3} \mathrm{CN}$.

With the exception of the axial $\alpha$-piperidyl proton resonances $\left(\mathrm{D}^{\prime}\right)$ each of the $\mathrm{pip}_{2} \mathrm{NNN}$ resonances is shifted downfield from that observed for the corresponding $\mathrm{Pd}\left(\mathrm{pip}_{2} \mathrm{NCN}\right) \mathrm{X}$ complex. For example, in $\mathrm{CD}_{3} \mathrm{CN}$ the para- and meta-pyridyl proton resonances (A/B) are shifted downfield by $\sim 1 \mathrm{ppm}\left([\mathrm{Cl}]^{+}, 1.12 /\right.$ $\left.0.74 ;[\mathrm{Br}]^{+}, 1.13 / 0.75 ;[\mathrm{I}]^{+}, 1.1 / 0.72 \mathrm{ppm}\right)$ from those of $\mathrm{Pd}\left(\mathrm{pip}_{2}{ }^{-}\right.$ NCN)X. The shifts are smaller for the benzylic protons, $C\left([\mathrm{Cl}]^{+}\right.$,

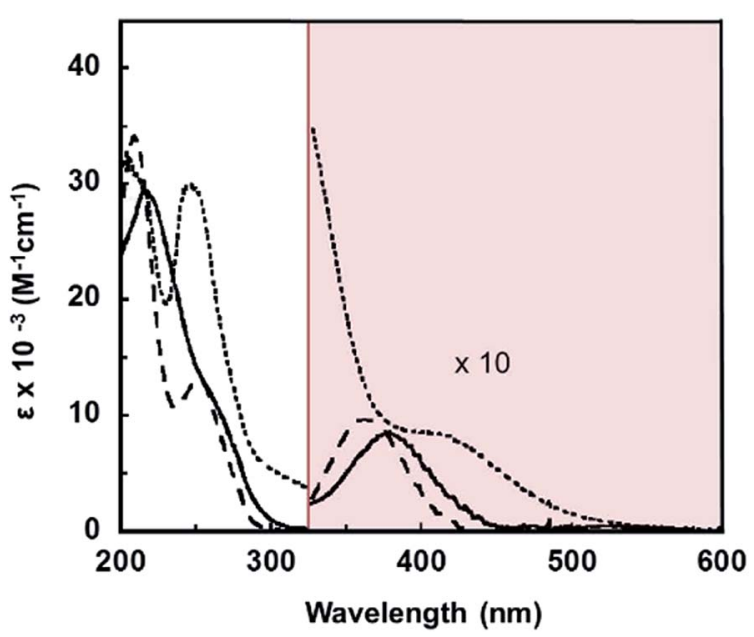

Fig. 1 UV-visible absorption spectra of $\left[\mathrm{Pd}\left(\operatorname{pip}_{2} \mathrm{NNN}\right) \mathrm{Cl}\right] \mathrm{Cl}\left(--{ }^{-}\right)$, $\left[\operatorname{Pd}\left(\operatorname{pip}_{2} N N N\right) \operatorname{Br}\right] B r(-)$ and $\left.\left[\operatorname{Pd}\left(\operatorname{pip}_{2} N N N\right)\right]\right] \mid(\cdots)$ in acetonitrile. The shaded area depicts tenfold magnification of the measured spectra. $\left.0.37 \mathrm{ppm} ;[\mathrm{Br}]^{+}, 0.37 \mathrm{ppm} ;[\mathrm{I}]^{+}, 0.36 \mathrm{ppm}\right)$ and the equatorial $\alpha-$ piperidyl proton, $\mathrm{D}^{\prime \prime}\left([\mathrm{Cl}]^{+}, 0.15 \mathrm{ppm} ;[\mathrm{Br}]^{+}, 0.12 \mathrm{ppm} ;[\mathrm{I}]^{+}, 0.12\right.$ ppm). By contrast, the axial $\alpha$-piperidyl proton resonance, $\mathrm{D}^{\prime}$, is shifted upfield by 0.19 and $0.14 \mathrm{ppm}$ in the spectra of $[\mathrm{Cl}]^{+}$and $[\mathrm{Br}]^{+}$, respectively, and downfield by $0.05 \mathrm{ppm}$ in the spectrum of $[\mathrm{I}]^{+}$. Thus, the gap between $\mathrm{D}^{\prime}$ and $\mathrm{D}^{\prime \prime}$ resonances $\left(\mathrm{D}^{\prime}-\mathrm{D}^{\prime \prime}:[\mathrm{Cl}]\right.$ $\mathrm{Cl}, 0.36$; [Br]Br, 0.47; [I] I, $0.67 \mathrm{ppm}$ ) is smaller than observed for $\mathrm{Pd}\left(\mathrm{pip}_{2} \mathrm{NCN}\right) \mathrm{X}(\mathrm{X}=\mathrm{Cl}, 0.67 ; \mathrm{Br}, 0.74 ; \mathrm{I}, 0.76 \mathrm{ppm})$ and increases along the series $\mathrm{Cl}<\mathrm{Br}<\mathrm{I}(\mathrm{Cl}, 0.33 ; \mathrm{Br}, 0.48 ; \mathrm{I}, 0.69 \mathrm{ppm})$. When $[\mathrm{X}]^{+}$is treated with $\mathrm{AgBF}_{4}$ to give $\mathrm{Pd}\left(\mathrm{pip}_{2} \mathrm{NNN}\right)$ (solvent) ${ }^{+}$, the $\alpha$ piperidyl protons appear as a singlet at $3.37 \mathrm{ppm}$, indicating that $\mathrm{Pd}-\mathrm{N}$ (piperidyl) bond cleavage and ring inversion are fast on the NMR timescale.

As noted for the $\mathrm{M}\left(\mathrm{pip}_{2} \mathrm{NCN}\right) \mathrm{X}(\mathrm{M}=\mathrm{Pd}, \mathrm{Pt} ; \mathrm{X}=\mathrm{Cl}, \mathrm{Br}, \mathrm{I})$ series, ${ }^{33,37}$ the ${ }^{1} \mathrm{H}$ NMR resonances for $[\mathrm{X}]^{+}$undergo a slight downfield shift along the $\mathrm{Cl}<\mathrm{Br}<\mathrm{I}$ series (Fig. 2). The deshielding effect going from the chloro to iodo complex is greatest $(0.40 \mathrm{ppm})$ for the piperidyl axial $\alpha$-proton resonance $\left(\mathrm{D}^{\prime}\right)$, exceeding shifts observed for the analogous $\mathrm{M}\left(\mathrm{pip}_{2} \mathrm{NCN}\right) \mathrm{X}$ complexes (Pt, 0.30; Pd, $0.16 \mathrm{ppm}){ }^{52}$ The sensitivity of the axial proton resonances is consistent with crystal structure data for $[\mathrm{Cl}] \mathrm{Cl}$ and $[\mathrm{Br}] \mathrm{BF}_{4}$ showing that the axial protons are $0.8-1.0 \AA$ closer to the halide ligand than the equatorial protons when the $\mathrm{Pd}$ center is at the equatorial position of the piperidyl $\mathrm{N}$ atom. The sensitivity of the remaining resonances to halide ligand substitution decreases along the $\mathrm{A}>\mathrm{D}^{\prime \prime}>\mathrm{C}>\mathrm{B}$ series, which can be rationalized in terms of through-bond and through-space interactions. The trend along the $\mathrm{Cl}<\mathrm{Br}<$ I series opposes the relative electronegativities of the halogen groups, as well as patterns in ${ }^{195} \mathrm{Pt}$ NMR experimental and computational results. ${ }^{53}$ However, this behavior has been noted for related compounds ${ }^{54}$ and is consistent with structural, spectroscopic and reactivity patterns of many transition metal complexes. ${ }^{55}$ Antipin, Grushin and coworkers have argued that similar trends in crystallographic and NMR data for trans $-\mathrm{Pd}\left(\mathrm{PPh}_{3}\right)_{2}(\mathrm{Ph}) \mathrm{X}(\mathrm{X}=$

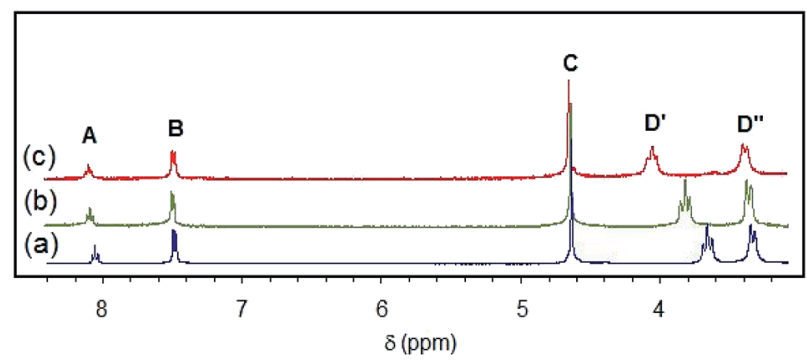

Fig. $2{ }^{1} \mathrm{H}$ NMR spectra of (a) $\left[\mathrm{Pd}\left(\mathrm{pip}_{2} \mathrm{NNN}\right) \mathrm{Cl}\right] \mathrm{Cl}$, (b) $\left[\mathrm{Pd}\left(\mathrm{pip}_{2} \mathrm{NNN}\right) \mathrm{Br}\right]$ $\mathrm{Br}$, (c) $\left.\left[\mathrm{Pd}\left(\mathrm{pip}_{2} \mathrm{NNN}\right)\right]\right]$ in $\mathrm{CD}_{3} \mathrm{CN}$. 
$\mathrm{F}, \mathrm{Cl}, \mathrm{Br}, \mathrm{I})$ can be understood in terms of filled/filled repulsions between the $d \pi$ orbitals of the metal center and the lone pair orbitals of the halide ligands. Infrared studies of five-coordinate $\operatorname{RuHX}(\mathrm{CO})\left(\mathrm{P}\left(\mathrm{CMe}_{3}\right)_{2} \mathrm{Me}\right)_{2}(\mathrm{X}=\mathrm{F}, \mathrm{Cl}, \mathrm{Br}, \mathrm{I})$ have established that the carbonyl stretching frequency increases along the $\mathrm{F}<\mathrm{Cl}<\mathrm{Br}$ $<$ I series, indicating that filled/filled repulsions decrease along this series. ${ }^{54,56}$ The deshielding of the pip $_{2}$ NNN ligand resonances along the $\mathrm{Cl}<\mathrm{Br}<$ I series is likewise consistent with decreasing filled/filled repulsions and electron releasing properties of the Pd-X unit.

\section{Anion dependence of the chemical shift}

The ${ }^{1} \mathrm{H}$ NMR spectra of samples of $[\mathrm{X}]^{+}$salts dissolved in $\mathrm{CDCl}_{3}$ are qualitatively similar to those obtained for samples dissolved in $\mathrm{CD}_{3} \mathrm{CN}$ with the surprising difference that the chemical shifts of the cation are strongly dependent on the nature of the anion. The influence of the counter anion is strongest for the metapyridyl and benzylic resonances which is the reverse of the sensitivity of these resonances to changes in the coordinated halide ligand. As shown in Fig. 3(a) and (b), the spectra of [Cl] $\mathrm{BF}_{4}$ and $[\mathrm{Cl}] \mathrm{Cl}$ in $\mathrm{CDCl}_{3}$ are distinctly different. The meta-pyridyl (B) and benzylic (C) proton resonances of the $\mathrm{BF}_{4}{ }^{-}$salt are shifted upfield by 0.27 and $0.23 \mathrm{ppm}$, respectively. By contrast, the chemical shifts of the remaining resonances are nearly identical to those of the chloride salt. When slightly more than one equivalent of tetrabutylammonium chloride, $\mathrm{TBACl}$, is added to a chloroform solution of $[\mathrm{Cl}] \mathrm{BF}_{4}$, the benzylic and meta-pyridyl resonances shift back to where they appeared for the $[\mathrm{Cl}] \mathrm{Cl}$ complex. However, when $\mathrm{TBABF}_{4}$ is added to a sample of $[\mathrm{Cl}] \mathrm{BF}_{4}$, no appreciable change $(<0.05 \mathrm{ppm})$ is observed in the chemical shift of any resonance. Likewise, addition of TBACl to the $[\mathrm{Cl}] \mathrm{Cl}$ sample does not shift any of the $[\mathrm{Cl}] \mathrm{Cl}$ resonances significantly. ${ }^{57}$ The strong influence of one equivalent of chloride ion on the NMR spectrum is indicative of an interaction between the cation and exogenous chloride anion. ${ }^{58-60}$ These effects are attenuated in $\mathrm{CD}_{3} \mathrm{CN}$. The ${ }^{1} \mathrm{H}$ NMR spectra of $[\mathrm{Cl}] \mathrm{Cl}$ and $[\mathrm{Cl}] \mathrm{BF}_{4}$ in $\mathrm{CD}_{3} \mathrm{CN}$ are very similar $(<0.07$ ppm difference), and addition of TBACl does not alter either spectrum. It is

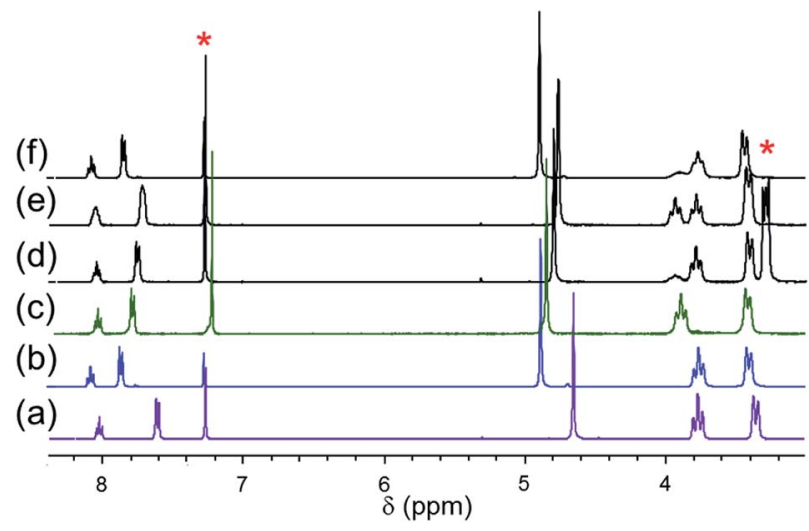

Fig. $3{ }^{1} \mathrm{H}$ NMR spectra of (a) $[\mathrm{Cl}]\left[\mathrm{BF}_{4}\right]$, (b) $[\mathrm{Cl}] \mathrm{Cl}$, (c) $[\mathrm{Br}] \mathrm{Br}$, (d) $1: 1[\mathrm{Cl}]$ $\left[\mathrm{BF}_{4}\right] / \mathrm{TBABr}$, (e) $1: 1[\mathrm{Cl}]\left[\mathrm{BF}_{4}\right] /[\mathrm{Br}] \mathrm{Br}$, (f) $1: 1[\mathrm{Cl}] \mathrm{Cl} /[\mathrm{Br}] \mathrm{Br}$ in $\mathrm{CDCl}_{3}$. * denotes solvent residual resonance and $\mathrm{TBAB}$ resonance. reasonable to expect that $\mathrm{Cl}^{-}$, as well as $[\mathrm{Cl}]^{+}$and $\mathrm{BF}_{4}{ }^{-}$, is better solvated in the higher dielectric solvent $\left(\varepsilon: \mathrm{CH}_{3} \mathrm{CN}, 37.5 ; \mathrm{CHCl}_{3}\right.$, 5.5). In keeping with this interpretation, addition of one equivalent of $\mathrm{TBABF}_{4}$ to a $\mathrm{CDCl}_{3}$ solution of the $[\mathrm{Cl}] \mathrm{Cl}$ modestly shifts the resonances toward their positions in the $[\mathrm{Cl}] \mathrm{BF}_{4}$ spectrum; for example, the benzylic resonance $\mathrm{C}$ shifts upfield by $0.09 \mathrm{ppm}$. These observations are consistent with decreasing cation/halide interaction with increasing ionic strength.

Conductivity measurements in acetonitrile confirm that $[\mathrm{Cl}]$ $\mathrm{BF}_{4}$ and $[\mathrm{Cl}] \mathrm{Cl}$ are essentially $1: 1$ electrolytes $(0.12 \mathrm{mM}[\mathrm{Cl}] \mathrm{Cl}$, $\left.138 \mathrm{~S} \mathrm{~cm}^{2} \mathrm{~mol}^{-1} ; 0.12 \mathrm{mM}[\mathrm{Cl}] \mathrm{BF}_{4}, 155 \mathrm{~S} \mathrm{~cm}^{2} \mathrm{~mol}^{-1}\right)$. Interestingly, even in dilute chloroform solution, both salts are essentially non-electrolytes $\left(0.12 \mathrm{mM}[\mathrm{Cl}] \mathrm{Cl},<2 \mathrm{~S} \mathrm{~cm}^{2} \mathrm{~mol}^{-1}\right.$; $\left.0.12 \mathrm{mM}[\mathrm{Cl}] \mathrm{BF}_{4},<2 \mathrm{~S} \mathrm{~cm}^{2} \mathrm{~mol}^{-1}\right)$. This observation and the aforementioned ${ }^{1} \mathrm{H}$ NMR data indicate that the cation-anion interaction for $[\mathrm{Cl}] \mathrm{Cl}$ in $\mathrm{CDCl}_{3}$ is stronger than for $[\mathrm{Cl}] \mathrm{BF}_{4}$ and places the metal complex in a significantly different chemical environment than for $[\mathrm{Cl}] \mathrm{BF}_{4}$. The similarity between the spectra of $[\mathrm{Cl}] \mathrm{BF}_{4}$ in $\mathrm{CDCl}_{3}$ and $\mathrm{CD}_{3} \mathrm{CN}$, as well as the weak Lewis basicity of $\mathrm{BF}_{4}{ }^{-}$, are consistent with conventional ionpairing. On the other hand, the cation-anion interaction for $[\mathrm{Cl}] \mathrm{Cl}$ in $\mathrm{CDCl}_{3}$ causes a more significant perturbation of the NMR spectrum, possibly because the chloride counterion is engaged in an inner-sphere interaction with the metal to form a five-coordinate complex. Such a structure must be fluxional or symmetric such that the equivalency of the piperidyl groups is preserved on the NMR timescale.

The sensitivity of certain resonances to substitution of the halide ligand or the counter-anion is convenient for investigations of the influence of halide anion in mixtures. For example, when one equivalent of $\mathrm{TBABr}$ was added to $\mathrm{CDCl}_{3}$ solution of $[\mathrm{Cl}] \mathrm{BF}_{4}$ (Fig. 3(d)), each resonance (except $\mathrm{D}^{\prime}$ ) appears at chemical shifts that are close to the average values for pure [Cl] $\mathrm{BF}_{4}$ and $[\mathrm{Br}] \mathrm{Br}$ solutions (e.g., $C: 4.79 \mathrm{ppm}(4.65+4.89) / 2=$ $4.77 \mathrm{ppm} ; B: 7.75 \mathrm{ppm}(7.83+7.61) / 2=7.72 \mathrm{ppm})$. Although the solution is a mixture of several species (i.e., $[\mathrm{X}] \mathrm{BF}_{4}$ and $[\mathrm{X}] \mathrm{X}$ where $\mathrm{X}=\mathrm{Cl}, \mathrm{Br}$ ), the coordinated halide has little effect on the chemical shifts and consequently they are close to the averaged values. The $\mathrm{D}^{\prime}$ protons give rise to two distinct resonances in a $3: 1$ intensity ratio (Fig. 3(d)). The less intense resonance (3.92 ppm) is nearly coincident with that of the equatorial $\alpha$-piperidyl proton resonance of $[\mathrm{Br}] \mathrm{Br}(3.93 \mathrm{ppm})$, whereas the more intense resonance $(3.75 \mathrm{ppm})$ is coincident with the $\alpha$-piperidyl proton resonance of $[\mathrm{Cl}] \mathrm{Cl}(3.75 \mathrm{ppm})$. Thus, only about $25 \%$ of the chloride ligand is replaced by bromide confirming the preference for chloride over bromide discussed previously. Assuming that the coordinated halide does not influence the chemical shifts of $\mathrm{B}$ and $\mathrm{C}\left(\right.$ i.e., $\left.\delta[\mathrm{Cl}] \mathrm{BF}_{4}\right)=\delta\left([\mathrm{Br}] \mathrm{BF}_{4}\right) ; \delta([\mathrm{Cl}] \mathrm{Br}=$ $\delta([\mathrm{Br}] \mathrm{Br}) ; \delta([\mathrm{Br}] \mathrm{Cl})=\delta([\mathrm{Cl}] \mathrm{Cl}))$ and that the $[\mathrm{Cl}] \mathrm{X}:[\mathrm{Br}] \mathrm{X}$ ratio is $3: 1$ (i.e., the $[\mathrm{X}] \mathrm{Cl}:[\mathrm{X}] \mathrm{Br}$ ratio is $1: 3 ; \mathrm{X}=\mathrm{Cl}, \mathrm{Br}$ ), we estimate from the observed chemical shift that in a $1: 1[\mathrm{Cl}] \mathrm{BF}_{4}: \mathrm{TBABr}$ mixture, the $\mathrm{BF}_{4}{ }^{-}$ion pair and the halide adduct $[\mathrm{X}] \mathrm{X}$ are in a $9: 10$ ratio. This implies that the interaction strengths of $\mathrm{BF}_{4}{ }^{-}$ and $\mathrm{Br}^{-}$are similar. Furthermore, making similar assumptions about a $1: 1[\mathrm{Cl}] \mathrm{BF}_{4}: \mathrm{TBACl}$ mixture leads to the conclusion that the $\mathrm{BF}_{4}{ }^{-}$ion pair and the $\mathrm{Cl}^{-}$adduct $[\mathrm{Cl}] \mathrm{Cl}$ are in a $2: 5$ 
ratio, confirming that association with $\mathrm{Cl}^{-}$is stronger than with $\mathrm{BF}_{4}^{-}$.

When $[\mathrm{Cl}] \mathrm{BF}_{4}$ is mixed with one equivalent of $[\mathrm{Br}] \mathrm{Br}$ at room temperature $\left(22^{\circ} \mathrm{C}\right)$, the aromatic and benzylic resonances are broad and appear at average chemical shifts of the corresponding resonances of the pure solutions (Fig. 4(e)). The two $\mathrm{D}^{\prime}$ piperidyl resonances appear in a 1:1 intensity ratio and are coincident with the $\mathrm{D}^{\prime}$ resonances in the spectra of $[\mathrm{Cl}] \mathrm{Cl}$ and $[\mathrm{Br}] \mathrm{Br}$, respectively. As the $[\mathrm{Cl}] \mathrm{BF}_{4} /[\mathrm{Br}] \mathrm{Br}$ mixture is cooled, the aromatic and benzylic resonances split, revealing two sets of nearly overlapping resonances (Fig. $4(\mathrm{c}-\mathrm{d})$ ). By contrast, the $\mathrm{D}^{\prime}$ and other piperidyl resonances sharpen (Fig. 4). The coalescence temperatures $\left(T_{\mathrm{c}}\right)$ of $\mathrm{A}, \mathrm{B}$ and $\mathrm{C}$ are $\sim 25{ }^{\circ} \mathrm{C}$. The two $\mathrm{D}^{\prime}$ resonances coalesce at $\sim 60^{\circ} \mathrm{C}$ but no coalescence is observed for the diastereotopic $\alpha$-piperidyl resonances, $\mathrm{D}^{\prime}$ and $\mathrm{D}^{\prime \prime}$, at $\leq 60{ }^{\circ} \mathrm{C}$ (Fig. 4(f)). The Eyring plot of $\mathrm{D}^{\prime}$ resonance is slightly nonlinear, becoming more shallow at low temperature. This behavior suggests underlying complexity, such as a change in rate-limiting step. Under the assumption of linearity, $\Delta H^{\ddagger}$ and $\Delta S^{\ddagger}$ are estimated to be approximately $11 \mathrm{kcal} \mathrm{mol}^{-1}$ and $-0.01 \mathrm{kcal} \mathrm{mol}^{-1} \mathrm{~K}^{-1}$, respectively. These values are in good agreement with those for halide exchange reactions of square planar $\mathrm{Pt}(\mathrm{II})^{61,62}$ and $\mathrm{Pd}(\mathrm{II})^{63}$ complexes with amine ligands $\left(\Delta H^{\ddagger}\right.$, 10 to $22 \mathrm{kcal} \mathrm{mol}^{-1}$; $\Delta S^{\ddagger},-30$ to $-16 \mathrm{cal} \mathrm{mol}^{-1} \mathrm{~K}^{-1}$ ).

Because of the similarities in the spectra of $[\mathrm{Cl}] \mathrm{Cl}$ and $[\mathrm{Br}] \mathrm{Br}$ in $\mathrm{CDCl}_{3}$, the changes in chemical shifts are comparatively modest when $[\mathrm{Cl}] \mathrm{Cl}$ is mixed with one equivalent of $[\mathrm{Br}] \mathrm{Br}$ (Fig. 5(e)). As expected, $[\mathrm{Cl}]^{+}$is favored over $[\mathrm{Br}]^{+}$, as indicated by the $3: 1$ intensity ratio of the $\mathrm{D}^{\prime}$ resonances. As the solution is cooled, the aromatic and benzylic resonances, A, B and C, broaden but no splitting is observed at $\geq-15{ }^{\circ} \mathrm{C}$ (Fig. $5(\mathrm{c}-\mathrm{d}$ )). On the other hand, the piperidyl resonances, $\mathrm{D}^{\prime}$ and $\mathrm{D}^{\prime \prime}$ (and also $\mathrm{E}$ and $\mathrm{F}$, not shown here), are sharp at $<0{ }^{\circ} \mathrm{C}$. The two $\mathrm{D}^{\prime}$ resonances coalesce at approximately $40{ }^{\circ} \mathrm{C}$. At $60{ }^{\circ} \mathrm{C}$, the diastereotopic $\alpha$-piperidyl resonances, $\mathrm{D}^{\prime}$ and $\mathrm{D}^{\prime \prime}$, are slightly closer to coalescence than in the spectrum of $1: 1\left[\mathrm{Cl}^{2}\right] \mathrm{BF}_{4} /[\mathrm{Br}] \mathrm{Br}$ (Fig. 4(f)). The estimation of thermodynamic parameters for the

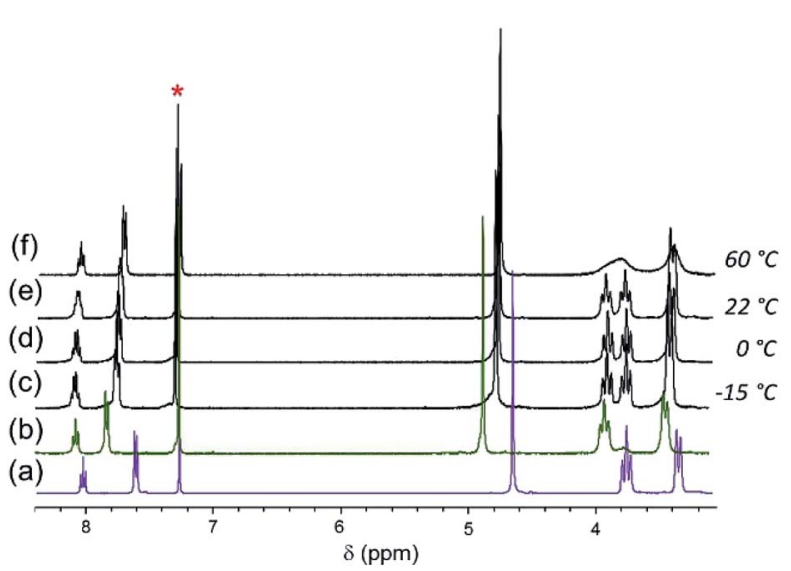

Fig. $4{ }^{1} \mathrm{H}$ NMR spectra of (a) $[\mathrm{Cl}]\left[\mathrm{BF}_{4}\right]$ and (b) $[\mathrm{Br}] \mathrm{Br}$ in $\mathrm{CDCl}_{3}$. Spectra of a $1: 1$ mixture of $\left[\mathrm{Cl}_{\mathrm{BF}} /[\mathrm{BB}] \mathrm{Br}\right.$ at different temperatures $(\mathrm{c})-(\mathrm{f})$ as shown in the picture. ${ }^{*}$ denotes solvent residual resonance. halide ligand exchange is complicated due to the inequality in the intensity ratio of the two $\mathrm{D}^{\prime}$ resonances.

Additionally, as the $\mathrm{D}^{\prime}$ resonances approach coalescence, the $\mathrm{D}^{\prime}$ and $\mathrm{D}^{\prime \prime}$ resonances begin to move toward each other (Fig. 5(g)). Consequently, because of the exchange process between $\mathrm{D}^{\prime}$ and $\mathrm{D}^{\prime \prime}$, the system can no longer be analyzed as two resonances coalescing. Treating the system as an unequally populated two-site exchange system, ${ }^{64,65}$ with a coalescence temperature between $40-45^{\circ} \mathrm{C}$ gives the barrier to halide ligand exchange $\left(\Delta G^{\ddagger}\right)$ between $15.7-15.9 \mathrm{kcal} \mathrm{mol}^{-1}$. Assuming the same $\Delta S^{\ddagger}$ as the $1: 1[\mathrm{Cl}] \mathrm{BF}_{4} /[\mathrm{Br}] \mathrm{Br}$ mixture $\left(-0.01 \mathrm{kcal} \mathrm{mol}^{-1}\right)$, $\Delta H^{*}$ is calculated to be in the $12.5-12.7 \mathrm{kcal} \mathrm{mol}^{-1}$ range. On the other hand, the barrier to exchange for the $\left[\mathrm{Cl}^{-} \mathrm{BF}_{4} /[\mathrm{Br}] \mathrm{Br}\right.$ mixture is calculated to be between $16.2-16.4 \mathrm{kcal} \mathrm{mol}^{-1}$ and $\Delta H^{\ddagger}$ at a coalescence temperature between $55-60{ }^{\circ} \mathrm{C}$ is in the 12.9-13.1 $\mathrm{kcal} \mathrm{mol}^{-1}$ range.

For a rate-determining intra-molecular rearrangement (e.g., $[\mathrm{Br}] \mathrm{Cl} \leftrightarrow[\mathrm{Cl}] \mathrm{Br})$, the dynamic process responsible for the coalescence of two different $\mathrm{D}^{\prime}$ resonances, assigned to $[\mathrm{Cl}]^{+}$and $[\mathrm{Br}]^{+}$, is proposed to involve a 5 -coordinate transition state. In other words, the barrier to halide ligand exchange likely reflects the instability of a 5-coordinate transition state species relative to $[\mathrm{X}]^{+}$or the $[\mathrm{X}]^{+} /$anion adduct. Therefore, assuming that the $\mathrm{BF}_{4}{ }^{-}$is not directly involved, for both $[\mathrm{Cl}] \mathrm{BF}_{4} /[\mathrm{Br}] \mathrm{Br}$ and $[\mathrm{Cl}] \mathrm{Cl} /$ $[\mathrm{Br}] \mathrm{Br}$ mixtures, the transition state species is expected be essentially the same. Apart from the error introduced by the estimation methods, the variation in the barrier to halide ligand exchange values can be attributed to the presence of $\mathrm{BF}_{4}{ }^{-}$in one of the mixtures. The facts that the conductivity measurements suggest a strong interaction between the cation and $\mathrm{BF}_{4}{ }^{-}$and the mixing experiments show that $[\mathrm{X}] \mathrm{BF}_{4}$ forms even if there is enough halide to coordinate to all $[\mathrm{X}]^{+}$in a solution $(\mathrm{X}=\mathrm{Cl}, \mathrm{Br})$, indicate that displacement of $\mathrm{BF}_{4}{ }^{-}$is required before halide ligand exchange can occur. If the displacement of $\mathrm{BF}_{4}{ }^{-}$is involved in the rate determining step, the overall reaction

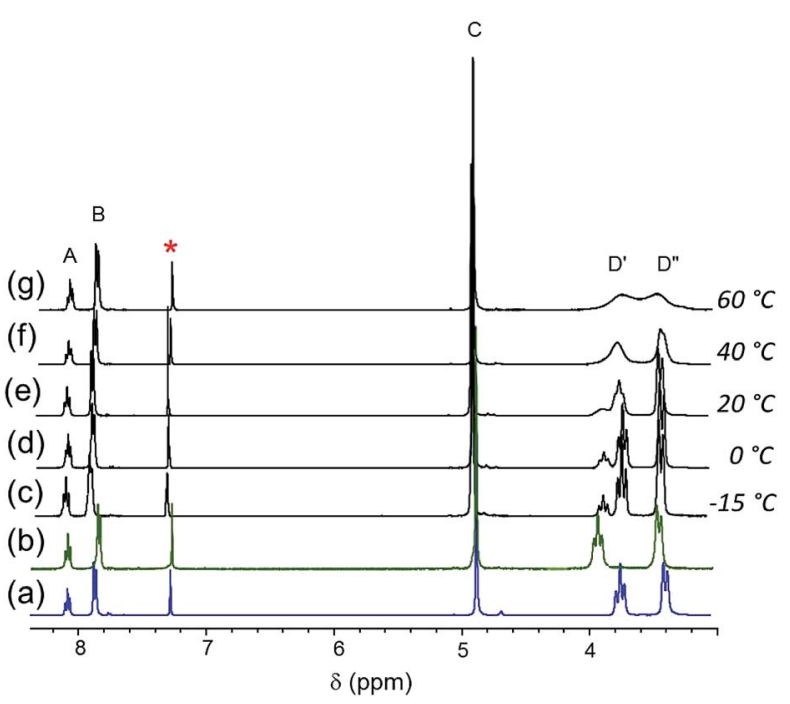

Fig. $5{ }^{1} \mathrm{H}$ NMR spectra of (a) $[\mathrm{Cl}] \mathrm{Cl}$ and (b) $[\mathrm{Br}] \mathrm{Br}$ in $\mathrm{CDCl}_{3}$. Spectra of $1: 1$ mixture of $[\mathrm{Cl}] \mathrm{Cl} /[\mathrm{Br}] \mathrm{Br}$ at different temperatures $(\mathrm{c})-(\mathrm{g})$ as shown in the picture. ${ }^{*}$ denotes solvent residual resonance. 
pathway is anticipated to have a higher activation barrier. Another possibility is that the rate determining step is bimolecular, and the rate of exchange and the coalescence temperature depend on halide ion concentration. Since the halide ion concentration is higher for the $[\mathrm{Cl}] \mathrm{Cl} /[\mathrm{Br}] \mathrm{Br}$ mixture, a lower barrier is expected, which is qualitatively consistent with what we have observed. It is noteworthy that the ionic strength of the mixture is not expected to have a significant influence since according to conductivity measurements the solutions do not contain many free ions. Although the water resonance shifts upfield as the temperature is raised in both mixtures, this does not influence the chemical shifts of the complexes' resonances measurably.

There is precedent for the interaction of four-coordinate palladium(II) complexes with exogenous halide anions. ${ }^{\mathbf{6 6 , 6 7}}$ For example, the conductivity measurements and NMR spectroscopy show that five coordinate $\operatorname{Pd}\left(\mathrm{N}^{\wedge} \mathrm{N}^{\wedge} \mathrm{N}\right)\left(\mathrm{CH}_{3}\right) \mathrm{Cl}\left(\mathrm{N}^{\wedge} \mathrm{N}^{\wedge} \mathrm{N}=2\right.$ (2-((2'-pyridylmethylene)amino)ethyl)pyridine) is favored at low temperatures in chlorinated solvents, whereas a square planar geometry with $\mathrm{Cl}^{-}$as the counter anion is observed in acetonitrile. At higher temperatures, the neutral species with bidentate $\mathrm{N}^{\wedge} \mathrm{N}^{\wedge} \mathrm{N}$ ligand forms regardless of the solvent. ${ }^{66}$ Not surprisingly, the flexibility of the $\mathrm{N}^{\wedge} \mathrm{N}^{\wedge} \mathrm{N}$ ligand stabilizes the five coordinate species at low temperatures in non-coordinating solvents. A similar $\operatorname{Pd}(\mathrm{II})$ complex with a phosphorusbis(nitrogen) ligand, $\left[\mathrm{Pd}\left(\eta^{3}-\mathrm{PNN}\right) \mathrm{CH}_{3}\right] \mathrm{Cl}(\mathrm{PNN}=\mathrm{N}$-(2-(diphenylphosphino)benzylidene)(2-((2-pyridyl)ethyl)amine)) is reported to be ionic in acetonitrile and molecular in chloroform as indicated by conductivity measurements. ${ }^{67}$ Compared to the $\mathrm{N}^{\wedge} \mathrm{N}^{\wedge} \mathrm{N}$ and $\mathrm{PNN}$ ligands, the $\mathrm{pip}_{2} \mathrm{NNN}$ ligand is more rigid, and regardless of solvent or temperature no evidence of asymmetric or bi-dentate coordination is observed by ${ }^{1} \mathrm{H}$ NMR spectroscopy. The preservation of symmetry in the ${ }^{1} \mathrm{H}$ NMR spectra could be due to fast exchange, ion pairing or formation of an adduct that preserves the mirror plane symmetry. In the latter case, one possibility is to position the $\operatorname{pip}_{2} \mathrm{NNN}$ and the two halide ligands in the same coordination plane. A more likely possibility is the preservation of the $C_{2 \mathrm{v}}$ symmetry by positioning the halide ligands above and below the plane defined by pip $_{2} \mathrm{NNN}$.

To assess the strength of the association between the halide counterion and the palladium cation, ${ }^{1} \mathrm{H}$ NMR spectra were recorded of a chloroform solution of $[\mathrm{Cl}] \mathrm{Cl}$ at different concentrations. The effective association constant was estimated $^{68}$ to be $\sim 10^{4} \mathrm{M}^{-1}$ from variations in the meta-pyridyl resonance shifts, indicating strong binding of the counter halide (Fig. 6). The fact that $[\mathrm{Cl}] \mathrm{Cl}$ solutions are nonconductive even at low concentrations supports the notion that the interaction between the $[\mathrm{Cl}]^{+}$and $\mathrm{Cl}^{-}$is strong. The red curve represents the fitting carried out with the assumption that there are only two species in solution, namely one with a specific interaction between the cation and the anion and the other fully dissociated. The species with a specific interaction is represented by the $[\mathrm{Cl}] \mathrm{Cl}$ chemical shift and the fully dissociated species, $[\mathrm{Cl}]^{+} \mathrm{Cl}^{-}$, is represented by the $[\mathrm{Cl}] \mathrm{BF}_{4}$ chemical shift. Two factors are considered for the poor fit of the red curve. First is the presence of a third form of the complex, $[\mathrm{Cl}]^{+} / \mathrm{Cl}^{-}$, in which the cation and the anion are paired in a non-specific

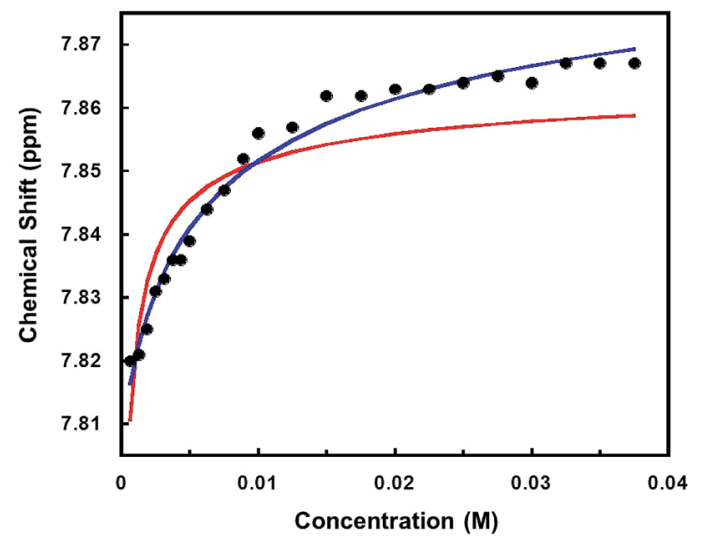

Fig. 6 The chemical shifts of meta $\mathrm{CH}$ protons vs. concentration of $[\mathrm{Cl}] \mathrm{Cl}(0.0006-0.04 \mathrm{M})$ in $\mathrm{CDCl}_{3}$. The red and blue curves illustrate the best-fit curves according to: $\delta=\delta_{[\mathrm{Cl}]^{+} \mathrm{x}^{-}}+\left(\left(\delta_{[\mathrm{Cl}] \mathrm{Cl}}-\delta_{[\mathrm{Cl}]^{+} \mathrm{x}^{-}}\right) / 2 \mathrm{C}\right)\left(K_{\mathrm{d}}+2 \mathrm{C}\right.$ $\left.-\left[\left(K_{d}+2 C\right)^{2}-4 C^{2}\right]^{1 / 2}\right)$, where $C$ is the concentration of $[C l]^{+}$. For the red curve, $\mathrm{X}=\mathrm{BF}_{4}, K_{\mathrm{a}}=1 / K_{\mathrm{d}}=2.4 \times 10^{4} \mathrm{M}^{-1}$, the chemical shift at infinite dilution $\left(\delta_{[\mathrm{Cl}]^{+} X^{-}}\right)$is assumed to be that of a solution of $\left[\mathrm{Cl}^{-} \mathrm{BF}_{4}\right.$ $(7.618 \mathrm{ppm})$ and the chemical shift of the fully associated species $\left(\delta_{[\mathrm{Cl}]}\right.$ $\mathrm{Cl}$ ) is assumed to be that of a solution of $[\mathrm{Cl}] \mathrm{Cl}(7.867 \mathrm{ppm})$. For the blue curve, the chemical shifts at infinite dilution and full association are optimized to obtain the best fit, $\mathrm{X}=\mathrm{Cl}, K_{\mathrm{a}}=194 \mathrm{M}^{-1}, \delta_{[\mathrm{Cl}]^{+} \mathrm{X}^{-}}=$ $7.808 \mathrm{ppm}, \delta_{[\mathrm{Cl}] \mathrm{Cl}}=7.897 \mathrm{ppm}$.

manner. The second reason is that the $[\mathrm{Cl}] \mathrm{BF}_{4}$ chemical shift is not a good representative for the chemical shift of the fully dissociated $[\mathrm{Cl}]^{+} \mathrm{Cl}^{-}$species. On the contrary, the lack of conductivity and ${ }^{1} \mathrm{H}$ NMR spectroscopy suggest an interaction between the $[\mathrm{Cl}]^{+}$cation and the $\mathrm{BF}_{4}{ }^{-}$counter anion. Thus, the $[\mathrm{Cl}] \mathrm{BF}_{4}$ spectrum may resemble more to the spectrum of the ion paired species. However, it is not expected to be the same since the interaction of $\mathrm{Cl}^{-}$with the cation is stronger than $\mathrm{BF}_{4}$.

When the chemical shifts of the two limiting species are assumed to be different than the ones of $[\mathrm{Cl}] \mathrm{Cl}$ and $[\mathrm{Cl}] \mathrm{BF}_{4}$ and allowed to be varied along with $K_{\mathrm{a}}$, a better fit is obtained (Fig. 6 , blue curve). In this case, the calculated chemical shifts of the species at full association (7.897 ppm) and infinite dilution (7.808 ppm) are higher than the chemical shifts of [Cl]Cl (7.867 ppm) and $[\mathrm{Cl}] \mathrm{BF}_{4}(7.618 \mathrm{ppm})$, respectively, whereas the $K_{\mathrm{a}}$ $\left(\sim 10^{2}\right)$ is two orders of magnitudes lower. Since conductometry does not support a high degree of dissociation at low concentrations, it is probable that the chemical shift calculated for the species at infinite dilution is actually that of the ion paired species $\left([\mathrm{Cl}]^{+} / \mathrm{Cl}^{-}\right)$. It should be added that unlike other $\operatorname{Pd}(\mathrm{II})$ complexes, ${ }^{58}$ significant formation of charged aggregates at high concentrations is not supported by conductometry. No appreciable change in the conductivity with concentration increase was recorded when the concentration of the $[\mathrm{Cl}] \mathrm{Cl}$ solution was raised to $0.01 \mathrm{M}$.

An associative mechanism is favored for ligand exchange reactions of related $\mathrm{Pd}(\mathrm{II})$ pincer ligand complexes, ${ }^{\mathbf{6 9 , 7 0}}$ as in the case of insertion of CO into the $\mathrm{Pd}-\mathrm{C}$ bond of $\mathrm{Pd}\left(\mathrm{Me}_{4} \mathrm{NNN}\right) \mathrm{R}^{+}$ type cations $\left(\mathrm{Me}_{4} \mathrm{NNN}=2,6\right.$-bis(dimethylamine-methyl)pyridine; $\mathrm{R}=$ methyl, phenyl, naphthyl). In that case, the transient species were modeled as Pd being coordinated by the $\mathrm{Me}_{4} \mathrm{NNN}$ ligand in a bidentate fashion along with the $\mathrm{R}$ and $\mathrm{CO}$ 


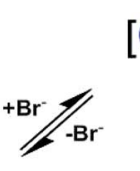

$[\mathrm{Cl}] \mathrm{Br}$

$[\mathrm{Br}] \mathrm{Cl}$

$[\mathrm{Cl}]^{+}$

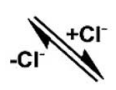

$+\mathrm{Cl}^{-}$

$[\mathrm{Br}]^{+}$

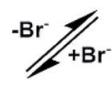

$[\mathrm{Br}] \mathrm{Br}$
Scheme 2 Suggested mechanism of halide exchange in $\mathrm{CDCl}_{3}$ based on the ${ }^{1} \mathrm{HNMR}$ data (Fig. 5). [X]X represents $\left[\mathrm{Pd}\left(\mathrm{pip}_{2} \mathrm{NNN}\right)(\mathrm{X})\right]^{+}$associated with $X^{-}(X=C l, B r)$.

groups. Interestingly, although a five-coordinate structure was not energetically favored; the transition state was found to be stabilized by an interaction between the non-coordinated amine and the Pd center. In general, a five-coordinate intermediate(s) and/or a transition state(s) with either square pyramidal or trigonal bipyramidal geometries are proposed for square planar Pd(II) complexes. As illustrated in Scheme 2, the accumulated data are consistent with association of the cation and halide anion prior to halide exchange, which is suggested to involve a five-coordinated intermediate.

There is considerable evidence that the equilibrium lies toward the $\mathrm{Cl}^{-}$coordination. A reaction profile for the top portion of the scheme describing $\mathrm{Cl} / \mathrm{Br}$ exchange is shown in Scheme 3. The reaction profile takes shape depending on the nature of the leaving and the entering ligands. When the leaving group, $\mathrm{Cl}^{-}$, is bonded more strongly to Pd than the entering group, $\mathrm{Br}^{-}$, the transition state is anticipated to have more $\mathrm{Pd} \cdots$ $\mathrm{Cl}$ bond dissociation character. It is noteworthy that, since in most cases $\mathrm{Br}^{-}$bonds more tightly to $\mathrm{Pd}(\mathrm{II})$ than $\mathrm{Cl}^{-}$, a reaction profile in which the transition state with more $\mathrm{Pd} \cdots \mathrm{Br}$ bond dissociation character is more commonly encountered. In the present case, the size of the $\mathrm{Cl}^{-}$ligand and the filled/filled

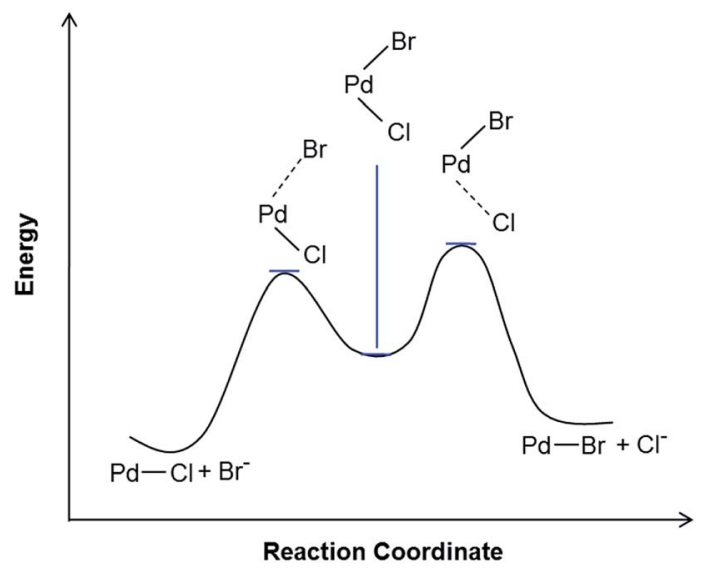

Scheme 3 Proposed reaction profile for the halide exchange reaction; $[\mathrm{Cl}]^{+}+\mathrm{Br}^{-} \rightarrow[\mathrm{Br}]^{+}+\mathrm{Cl}^{-}$. The transition state is proposed to have more $\mathrm{Pd} \cdots \mathrm{Cl}$ bond dissociation character. repulsions between the $\mathrm{d} \pi$ orbitals of the metal center and the lone pair orbitals of the halide ligand are anticipated to contribute to the preference for $\mathrm{Cl}^{-}$over $\mathrm{Br}^{-}$coordination.

\section{Conclusions}

Although palladium complexes with ECE type pincer ligands have been studied extensively, neutral NNN pincer ligands with pyridine central moieties have not been explored as much. New square planar palladium(II) complexes with pip $_{2} \mathrm{NNN}$ pincer ligand have been prepared: $\left[\mathrm{Pd}\left(\mathrm{pip}_{2} \mathrm{NNN}\right) \mathrm{X}\right] \mathrm{X}(\mathrm{X}=\mathrm{Br}$, I). Unlike the NCN pincer analogue, formation of bridged $\mathrm{Pd}_{2} \mathrm{X}_{6}{ }^{2-}$ or single $\mathrm{PdX}_{4}{ }^{2-}$ anions $(\mathrm{X}=\mathrm{Cl}, \mathrm{Br}, \mathrm{I})$ from the same reaction set up is observed.

${ }^{1} \mathrm{H}$ NMR spectra of $\left[\mathrm{Pd}\left(\mathrm{pip}_{2} \mathrm{NNN}\right) \mathrm{X}\right] \mathrm{X}$ show that the presence of the halide anion has the strongest influence on the benzylic and meta-CH resonances, whereas variations in the halide ligand have the strongest influence on the furthest downfield $\alpha$ piperidyl resonance. This difference in sensitivity is used to study halide association. The difficulty in determination of the chemical shifts of the fully associated and fully dissociated species in a mixed anion solution lead to a somewhat broad estimation of the effective association constant $\left(\sim 10^{4} \mathrm{M}^{-1}\right.$ to $\left.10^{-2} \mathrm{M}^{-1}\right)$. An associative mechanism where the transition state has more $\mathrm{Pd} \cdots \mathrm{Cl}$ dissociation character is anticipated which indicates preference of $\mathrm{Cl}$ versus $\mathrm{Br}$ coordination due to the smaller size of $\mathrm{Cl}$ and the stronger filled/filled repulsions between $\mathrm{Pd} d \tau$ orbitals the $\mathrm{Cl}$ lone pair orbitals. The importance of exogenous halide anions on the kinetics of outersphere two-electron transfer has been noted for 5-coordinate palladium(II) complexes. ${ }^{71,72}$ The solvent and anion dependence of the interaction between the exogenous anion $\left(\mathrm{Cl}^{-}, \mathrm{Br}^{-}, \mathrm{BF}_{4}{ }^{-}\right)$ and the palladium cation $\left(\operatorname{Pd}\left(\operatorname{pip}_{2} \mathrm{NNN}\right) \mathrm{X}^{+}, \mathrm{X}=\mathrm{Cl}, \mathrm{Br}\right)$ open possibilities for further studies.

\section{Conflicts of interest}

There are no conflicts to declare.

\section{Acknowledgements}

The authors would like to express their gratitude to Dr Janette Krause for help with characterization. We thank the National Science Foundation (Grant CHE0134975) and the Arnold and Mabel Beckman Foundation for support. We also thank CWRU for support of the Center for Chemical Dynamics.

\section{References}

1 K. J. Szabó, Synlett, 2006, 811-824.

2 L. González-Sebastián and D. Morales-Morales, J. Organomet. Chem., 2019, 893, 39-51.

3 M. R. Eberhard, Org. Lett., 2004, 6, 2125-2128.

4 N. Selander and K. J. Szabó, Chem. Rev., 2011, 111, 20482076. 
5 M. Q. Slagt, D. A. P. van Zwieten, A. J. C. M. Moerkerk, R. J. M. K. Gebbink and G. van Koten, Coord. Chem. Rev., 2004, 248, 2275-2282.

6 M. Albrecht and G. van Koten, Angew. Chem., Int. Ed., 2001, 40, 3750-3781.

7 D. Morales-Morales and C. M. Jensen, The Chemistry of Pincer Compounds, Elsevier, 1st edn, 2007.

8 D. Morales-Morales, Pincer Compounds, Elsevier, 2018.

9 P. O'Leary, C. A. van Walree, N. C. Mehendale, J. Sumerel, D. E. Morse, W. C. Kaska, G. van Koten and R. J. M. K. Gebbink, Dalton Trans., 2009, 4289-4291.

10 M. Albrecht, R. A. Gossage, G. van Koten and A. L. Spek, Chem. Commun., 1998, 1003-1004.

11 M. Albrecht, N. J. Hovestad, J. Boersma and G. van Koten, Chem.-Eur. J., 2001, 7, 1289-1294.

12 M. Albrecht, M. Lutz, A. L. Spek and G. van Koten, Nature, 2000, 406, 970-974.

13 W. W. Gerhardt, A. J. Zucchero, J. N. Wilson, C. R. South, U. H. F. Bunz and M. Weck, Chem. Commun., 2006, 21412143.

14 J. He, A. M. Bohnsack, N. W. Waggoner, S. G. Dunning, V. M. Lynch, W. C. Kaska and S. M. Humphrey, Polyhedron, 2018, 143, 149-156.

15 G. Rodríguez, M. Albrecht, J. Schoenmaker, A. Ford, M. Lutz, A. L. Spek and G. van Koten, J. Am. Chem. Soc., 2002, 124, 5127-5138.

16 M. T. Johnson, Z. Džolić, M. Cetina, M. Lahtinen, M. S. G. Ahlquist, K. Rissanen, L. Öhrström and O. F. Wendt, Dalton Trans., 2013, 42, 8484-8491.

17 I. Davidi, D. Hermida-Merino, K. Keinan-Adamsky, G. Portale, G. Goobes and R. Shenhar, Chem.-Eur. J., 2014, 20, 6951-6959.

18 S. G. Churusova, D. V. Aleksanyan, A. A. Vasil'ev, E. Y. Rybalkina, O. Y. Susova, Z. S. Klemenkova, R. R. Aysin, Y. V. Nelyubina and V. A. Kozlov, Appl. Organomet. Chem., 2018, 32, e4360.

19 S. A. Burgess, A. Kassie, S. A. Baranowski, K. J. Fritzsching, K. Schmidt-Rohr, C. M. Brown and C. R. Wade, J. Am. Chem. Soc., 2016, 138, 1780-1783.

20 N. Cutillas, G. S. Yellol, C. de Haro, C. Vicente, V. Rodríguez and J. Ruiz, Coord. Chem. Rev., 2013, 257, 2784-2797.

21 M. Basauri-Molina, S. Hernández-Ortega and D. MoralesMorales, Eur. J. Inorg. Chem., 2014, 4619-4625.

22 J. Takaya and N. Iwasawa, J. Am. Chem. Soc., 2008, 130, 15254-15255.

23 J. Takaya and N. Iwasawa, J. Synth. Org. Chem., 2013, 71, 417424.

24 M. Mazzeo, M. Lamberti, A. Massa, A. Scettri, C. Pellecchia and J. C. Peters, Organometallics, 2008, 27, 5741-5743.

25 N. Solin, J. Kjellgren and K. J. Szabó, J. Am. Chem. Soc., 2004, 126, 7026-7033.

26 V. Subramaniyan, B. Dutta, A. Govindaraj and G. Mani, Dalton Trans., 2019, 48, 7203-7210.

27 E. Peris, J. A. Loch, J. Mata and R. H. Crabtree, Chem. Commun., 2001, 201-202.

28 S. G. Churusova, D. V. Aleksanyan, E. Yu. Rybalkina, O. Yu. Susova, V. V. Brunova, R. R. Aysin, Y. V. Nelyubina,
A. S. Peregudov, E. I. Gutsul, Z. S. Klemenkova and V. A. Kozlov, Inorg. Chem., 2017, 56, 9834-9850.

29 S. G. Churusova, D. V. Aleksanyan, E. Yu. Rybalkina, Y. V. Nelyubina, A. S. Peregudov, Z. S. Klemenkova and V. A. Kozlov, Polyhedron, 2018, 143, 70-82.

30 F.-F. Hung, S.-X. Wu, W.-P. To, W.-L. Kwong, X. Guan, W. Lu, K.-H. Low and C.-M. Che, Chem.-Asian J., 2017, 12, 145-158.

31 T. Thirunavukkarasu, H. A. Sparkes, K. Natarajan and V. G. Gnanasoundari, Appl. Organomet. Chem., 2018, 32, e4403.

32 J.-Y. Lee, J.-Y. Lee, Y.-Y. Chang, C.-H. Hu, N. M. Wang and H. M. Lee, Organometallics, 2015, 34, 4359-4368.

33 H. Jude, J. A. Krause Bauer and W. B. Connick, Inorg. Chem., 2002, 41, 2275-2281.

34 S. J. Farley, D. L. Rochester, A. L. Thompson, J. A. K. Howard and J. A. G. Williams, Inorg. Chem., 2005, 44, 9690-9703.

35 H. Jude, J. A. Krause Bauer and W. B. Connick, Inorg. Chem., 2005, 44, 1211-1220.

36 L.-L. Shi, Y. Liao, G.-C. Yang, Z.-M. Su and S.-S. Zhao, Inorg. Chem., 2008, 47, 2347-2355.

37 S. Tastan, J. A. Krause and W. B. Connick, Inorg. Chim. Acta, 2006, 359, 1889-1898.

38 L. F. Olsson, Inorg. Chem., 1986, 25, 1697-1704.

39 V. Anbalagan, R. Srinivasan and K. S. Pallavi, Transition Met. Chem., 2001, 26, 603-607.

40 A. Hofmann, D. Jaganyi, O. Q. Munro, G. Liehr and R. van Eldik, Inorg. Chem., 2003, 42, 1688-1700.

41 P. M. Gidney, R. D. Gillard and B. T. Heaton, J. Chem. Soc., Dalton Trans., 1973, 132-134.

42 F. D. Lewis, G. D. Salvi, D. R. Kanis and M. A. Ratner, Inorg. Chem., 1993, 32, 1251-1258.

43 W. Zhang, C. Bensimon and R. J. Crutchley, Inorg. Chem., 1993, 32, 5808-5812.

44 H. Kunkely and A. Vogler, J. Organomet. Chem., 1998, 559, 215-217.

45 C. L. Choi and D. Phillips, Mol. Phys., 1998, 94, 547-554.

46 K. H. Leung, W. Szulbinski and D. L. Phillips, Mol. Phys., 2000, 98, 1323-1330.

47 X.-X. Lu, E. C.-C. Cheng, N. Zhu and V. W.-W. Yam, Dalton Trans., 2006, 1803-1808.

$48 \mathrm{Z}$. Hui Zhang, X. He Bu, Z. Ang Zhu and Y. Ti Chen, Polyhedron, 1996, 15, 2787-2792.

49 C. B. Pamplin, S. J. Rettig, B. O. Patrick and B. R. James, Inorg. Chem., 2003, 42, 4117-4126.

50 P. Stoppioni, R. Morassi and F. Zanobini, Inorg. Chim. Acta, 1981, 52, 101-106.

51 S. M. Ansari, W. Robien, M. Schlederer and P. Wolschann, Monatshefte Chem., 1989, 120, 1003-1014.

52 The chemical shifts for $\mathrm{Pt}\left(\mathrm{pip}_{2} \mathrm{NCN}\right) \mathrm{X}$ were determined in $\mathrm{CDCl}_{3}$.

53 T. M. Gilbert and T. Ziegler, J. Phys. Chem. A, 1999, 103, 75357543.

54 J. P. Flemming, M. C. Pilon, O. Y. Borbulevitch, M. Y. Antipin and V. V. Grushin, Inorg. Chim. Acta, 1998, 280, 87-98.

55 K. G. Caulton, New J. Chem., 1994, 18, 25-41.

56 J. T. Poulton, M. P. Sigalas, K. Folting, W. E. Streib, O. Eisenstein and K. G. Caulton, Inorg. Chem., 1994, 33, 1476. 
57 As expected from the spectrum of TBACl, addition of TBACl shifts the water resonance in the $[\mathrm{Cl}] \mathrm{Cl}$ and $[\mathrm{Cl}] \mathrm{BF}_{4}$ spectra. Nevertheless, when a few equivalents of water are added to either $[\mathrm{Cl}] \mathrm{Cl}$ or $[\mathrm{Cl}] \mathrm{BF}_{4}$, no substantial shift is observed for the $[\mathrm{Cl}]^{+}$resonances.

58 B. Crociani, F. di Bianca, A. Giovenco and T. Boschi, Inorg. Chim. Acta, 1987, 127, 169-182.

59 A. Irving, K. R. Koch and M. Matoetoe, Inorg. Chim. Acta, 1993, 206, 193-199.

60 R. Romeo, N. Nastasi, L. M. Scolaro, M. R. Plutino, A. Albinati and A. Macchioni, Inorg. Chem., 1998, 37, 54605466.

61 U. Belluco, R. Ettorre, F. Basolo, R. G. Pearson and A. Turco, Inorg. Chem., 1966, 5, 591-593.

62 M. A. Tucker, C. B. Colvin and D. S. Martin, Inorg. Chem., 1964, 3, 1373-1383.

63 R. Roulet and H. B. Gray, Inorg. Chem., 1972, 11, 2101-2104.

64 H. Shanan-Atidi and K. H. Bar-Eli, J. Phys. Chem., 1970, 74, 961-963.
65 W. Egan, PhD thesis, Princeton University, 1971.

66 R. E. Rulke, J. M. Ernsting, A. L. Spek, C. J. Elsevier, P. W. N. M. van Leeuwen and K. Vrieze, Inorg. Chem., 1993, 32, 5769-5778.

67 R. E. Ruelke, V. E. Kaasjager, P. Wehman, C. J. Elsevier, P. W. N. M. van Leeuwen, K. Vrieze, J. Fraanje, K. Goubitz and A. L. Spek, Organometallics, 1996, 15, 3022-3031.

68 C. S. Wilcox, Frontiers in Supramolecular Organic Chemistry and Photochemistry, 1991, pp. 123-143.

69 C. H. Langford and H. B. Gray, Ligand Substitution Processes, W. A. Benjamin, Inc., Reading, 1966.

70 R. J. Cross, in Advances in Inorganic Chemistry, ed. A. G. Sykes, Academic Press, 1989, vol. 34, pp. 219-292.

71 S. Chatterjee, Cooperative Two-Electron Reagents of Lower Transition Metals of Group 10, University of Cincinnati, 2009.

72 D. E. Janzen, D. G. VanDerveer, L. F. Mehne, D. A. d. S. Filho, J.-L. Brédas and G. J. Grant, Dalton Trans., 2008, 1872-1882. 